\section{"DIRECT REPRESENTATION ON THE GENERAL MEDICAL COUNCIL." \\ To the Editors of THE LANCET.}

SIRS, - I am obliged for your insertion of my letter in your issue of June 27th and I hope you will find further space for the following resolution, which, on the motion of Dr. Woodcock and seconded by Mr. Holden of Preston, was unanimously adopted at the annual meeting of the Lancashire and Cheshire Branch held in Southport and also previously at the Council meeting: "That the members of this branch desire to express their great regret at the resignation of Mr. Wheelhouse and Sir Walter Foster, and to tender them their most grateful thanks for the long and valuable services which they have rendered to the profession in the General Medical Council." I am, Sirs, yours truly,

JAMES BARR,

Hon. Secretary, Lancashire and Cheshire Branch, British Medical Association.

Rodney-street, Liverpool, June 29th, 1896.

\section{To the Editors of The LANCET.}

SIRS,-In reply to the questions submitted to me by the Incorporated Medical Practitioners' Association, my views are :-

"1. That we require reform of the Medical Acts, and I would support any motion to that effect. 2. I would oppose any proposal to register midwives as independent practitioners. 3. I would support any motion condemning the holding of appointments under medical aid associations which make a profit out of their medical officer and who canvass from door to door. 4. I am in favour of increased representation on the Medical Council.";

I have been asked by several of those who supported me at the first election to stand again and I have consented to do so. I am, Sirs, yours faithfully,

Thomas M. Dolas, M.D. Durh.

\section{To the Editors of THe LANCET.}

SIns,-The Central Council of the Incorporated Medical Practitioners' Association, having decided to take a preliminary poll as to the probable chance of election of the various candidates, will feel obliged if all the gentlemen who intend to present themselves at the forthcoming election of direct representatives on the General Medical Council will send in their names to the secretary at this address on or before July 11th.--I am, Sirs, yours faithfully,

FrANK GREAVES,

Hon. Sec. Incorporated Medical Practitioners' Association. 11, Adam-street, Strand, W.C., June 29th, 1896.

\section{To the Editors of The LANCET.}

Sirs,-At the dinner subsequent to the meeting of the Lancashire and Cheshire Branch of the British Medical Association, held at Southport on June 24th, some gentlemen who were not present at the last stage of the meeting, when Mr. Horsley carried a resolution not on the agenda, agreed to and signed the following requisition, which has been duly forwarded. I am, Sirs, yours faithfully,

Colin CaMPBell.

"To Sir Walter Foster and Mr. C. G. Wheelhouse.

"Dear Sirs, - We the undersigned beg to tender you our sincere thanks for the faithful services you have rendered us for the past ten years as our representative in the General Medical Council, and hereby beg you to reconsider your decision as to withdrawing from your present position and allow us to nominate you for another term of office:-

"William Stewart, Southport. J. M. Chisholm, Liverpool. J. W. O'Hagan, Garston. B. Marshall, Atherton. Charles Torbitt, Pendleton. William Fraser, Salford. G. H. Broadbent, Manchester. W. H. Wolstenholme, Salford. Colin Campbell, Saddleworth. Lawson Tait, Birmingham. Geo. C. Kingsbur, , Blackpool. James Robinson, Bolton. Horace Jefferies, Bolton. Thos. Evans Fliteroft, Bolton. Charles Macfie, Bolton. Arthur Jones, Southport. E. H. Beaman, Southport. D. A. O' Sulliran, Southport. G. B. Barron, Soutbport. Makerfield.

Charles Pinkerton. Southport

Robert Harris, Southport.

G. Walker Steeves, Southport. Arthur Wood, Southport.

Geo. S. Wild, Bootle.

J. Lambert, Birkenhead.

H. Hamilton. Liverpool.

Henry Halton, Leigh.

C. A. Hill, Liverpool. Willows.

T. E. Hayward, Newton-le-Willows Charles Street, Newton-le-Willows. Walter Whitehead, Manchester.

D. J. Leech, Manchester."
Nathan Hannah, Ashton-in-

W. J. Robertson Dunn, Liverpool.

John W. Watkins, Newton-le-

THE COUNCIL OF THE ROYAL COLLEGE OF SURGEONS OF ENGLAND.

\author{
To the Editors of THE LANCET.
}

SIRs,-We have often had to complain of the reticence of members of the Council of this College, and hardly expected to have to accuse one of them of an opposite tendency. One may, however, question the propriety displayed by $\mathrm{Mr}$. Hardie, who on the eve of an important decision to be arrived at by a body of which he is a member rushes into print in order to justify his vote. What would be thought if his colleagues who held different views were to follow his example? We should then have the edifying spectacle of men who have to form a judicial conclusion bandying argaments beforehand in the public press! For the Council is a judicial body and it and not the Fellows will have ultimately to decide the questions under discussion. If Mr. Hardie's object is, as he states, to influence the Fellows in favour of his own views I venture to think that he has made a tactical mistake. The replies to his arguments are really so well known that I feel ashamed again to trouble your readers with them. I will, therefore, only ask Mr. Hardie three questions. 1. Are the Members an integral part of the College or not; are they in the eyes of the law the joint owners of the corporate property, and if so should they not have some control over the policy and expenditure of the College? 2. Does the Council as at present constituted in any way represent the Members; does it endeavour to ascertain their wishes and views on current questions and so far as possible carry them out; and does it protect their interests and support them against outsiders if appealed to? 3. Did Mr. Hardie, when he became a Fellow, do so because he might thus obtain a vote for the Council; and if this were the only privilege or advantage of the Fellowship would he have taken it? Mr. Hardie flounders about sadly when he endeavours to define the position of the Council. In one sentence he says that it is "an academic body with objects and functions apart from those of the profession generally"! In the next he says that it has to uphold the interests of those who hold its diploma, and a little further down he refers the Members to "voluntary associations."

I am, Sirs, yours faithfully,

W. G. Dickinson.

\title{
"TOXICOLOGICAL EFFECTS OF CREOLIN."
}

\section{To the Editors of THE LANCET.}

SIRS, - I observe in THE LANCET of June 27th a letter signed by the secretary of the Jeyes' Sanitary Compounds Company, in which reference is made to my recently published article on the "Toxicological Effects of Creolin." It is there said that my experiments were " carried on with creolin in practically undiluted form, and of course no one can expect good results." In reply permit me to say that my object was simply to ascertain whether the agents experimented with were poisons in the ordinary sense of the word. In face of the results obtained it appears to me simply absurd to deny that Jeyes' fluid or creolin is poisonous, and the fact that they may be diluted to a point of safety in no way entitles them to be described as "innocuous" or " nonpoisonous." Hydrocyanic acid, in the proportion of 1 in 1000 of water, is a perfectly safe dressing for the dog's skin, but this would not justify a druggist in selling pure hydrocyanic acid as non-poisonous, even if accompanied with directions regarding dilution.

I am, Sirs, yours obediently,

Royal Veterinary College, N.W., June 29th, 1896. FREDK. HOBDAY.

\section{"TRANSFUSION OF SALINE FLUID INTO} THE AXILLARY CELLULAR TISSUE IN CASES OF SEVERE HEMORRHAGE."

\section{To the Editors of THE LANCET.}

SiRs,-The thanks of our profession are due to $\mathrm{Mr}$. Arthur $H$. Dodd for the admirable communication from his pen which was published in your last issue, describing a brilliantly successful case of transfusion of saline fluid into the axillary cellular tissue in the treatment of serere 